\title{
EFFECTS OF HEMICASTRATION AND THE SUBSEQUENT ADMINISTRATION OF DRUGS IN THE MOUSE
}

\author{
LINDA FAWKE, AUDREY MORRIS AND P. S. BROWN \\ Departments of Pharmacology and Public Health, \\ University of Bristol, Bristol BS8 1 TD
}

(Received 30th December 1970, accepted 19th Fuly 1971)

\begin{abstract}
Summary. Compensatory hypertrophy of the remaining testis was not detected in mice hemicastrated at ages varying from 3 to 18 weeks, and killed 1, 2 or 3 weeks later. The response of hemicastrated mice to drugs and sex steroids was tested to see whether these animals were useful in studying the effects of antigonadotrophic substances. Seminal vesicle weight was significantly reduced by oestradiol, progesterone, methallibure and reserpine (though small doses of reserpine caused unexpected increases). Increase in testis weight was significantly reduced by oestradiol, methallibure, chlorpromazine and reserpine. Correction of seminal vesicle and increase in testis weight for initial body weight was found to be valid and useful. Hemicastrated mice were used to test drugs which inhibit the synthesis of biogenic monoamines: $p$-chlorophenylalanine reduced seminal vesicle weight but $\alpha$-methyltyrosine was without effect.
\end{abstract}

\section{INTRODUCTION}

These experiments were designed firstly to investigate whether compensatory hypertrophy occurs over short periods in the hemicastrated male mouse, as Grant (1957) has reported it to do in the rat, and secondly whether the hemicastrated mouse could be useful in testing substances likely to influence gonadotrophin secretion. Because of the possible rôle of 5-hydroxytryptamine (5HT) and catecholamines in the control of gonadotrophin secretion, particular emphasis was placed upon drugs which inhibit their synthesis.

\section{MATERIALS AND METHODS}

Male OSI mice (from W. Clark, Oldham) were hemicastrated in random order under ether anaesthesia. The remaining testis and the seminal vesicles, together with the coagulating glands, were removed when the animals were killed and organs were fixed in $10 \%$ formol-saline before weighing.

\section{Search for compensatory hypertrophy}

Mice were hemicastrated at various ages from 3 to 18 weeks and killed 1, 2 or 3 weeks later. The weight of the remaining testes was compared with the weight 
of testes from intact animals of the same age. Alternate right and left testes were removed at hemicastration and their weights compared.

\section{Drug treatment of the hemicastrated mouse}

After removal of right testes on the 1st experimental day, mice were given five daily subcutaneous injections starting on the day after operation. Some groups were killed on the 8th day while, in others, injections were continued on alternate days from the 8 th to the 12th day and the animals were killed on the 15 th day. In all cases, the age at death was $41 \pm 1$ days. The following drugs were used: oestradiol benzoate (Organon), progesterone (Organon) and testosterone propionate (Organon), all given in arachis oil containing $10 \%$ benzyl alcohol; reserpine dissolved in the vehicle described by Burack, Weiner \& Hagen (1960) and diluted with saline; methallibure (ICI), DL-p-chlorophenylalanine (CPA) (Sigma, London) and DL- $\alpha$-methyl-p-tyrosine (MPT) (Sigma) suspended in saline containing $0.25 \%$ methylcellulose. Saline was used as the solvent for DL-p-chlorophenylalanine methyl ester hydrochloride (Kistner Laboratories) and DL- $\alpha$-methyltyrosine methyl ester hydrochloride (Sigma). Controls received the vehicles.

Variance in organ weights was high and an analysis of covariance (Snedecor, 1937) with corrections for initial body weight and initial testis weight was carried out using an Elliott 503 computer.

\section{RESULTS}

Search for compensatory hypertrophy

The weights of the testes $\left(\mathrm{TW}_{1}\right)$ removed at hemicastration from intact mice were compared with those of the remaining testes $\left(\mathrm{TW}_{2}\right)$ removed from mice of the same age which had been previously hemicastrated (Tables 1 and 2). The differences were never significant $(P>0.05$ in all cases and $P>0.1$ in twelve out of the fourteen comparisons which could be made).

In four groups, the weight of seminal vesicles from hemicastrated mice was compared with that of seminal vesicles from intact mice of the same age and in two cases was significantly reduced $(P<0 \cdot 05)$.

At eight of the eleven ages at which mice were hemicastrated, the right testes were heavier than the left, although this was not statistically significant in individual comparisons (Tables 1 and 2; comparisons between means (1) and (3)). Analysis of variance on the combined data after correction for initial body weight showed the difference between right and left testes to be significant $(\mathbf{F}=10.834$, d.f. $=1 / 37, P<0.01)$.

\section{Drug treatment of the hemicastrated mouse}

Table 3 shows the effects of treatment with gonadal steroids. Both oestradiol benzoate and progesterone, in the doses used, reduced seminal vesicle weight significantly and to a similar extent. The increase in testis weight was reduced significantly by oestradiol $(P<0.01)$ but not significantly by progesterone. Testosterone propionate had the expected effect on seminal vesicle weight but no significant effect on testis weight. 
TABLE 1

COMPARISON OF TESTIS WEIGHTS FROM MICE HEMICASTRATED 1 WEEK PREVIOUSLY AND INTACT MICE AT THE SAME AGE

\begin{tabular}{|c|c|c|c|c|c|c|c|}
\hline \multirow{3}{*}{$\begin{array}{c}\text { Age at } \\
\text { comparison } \\
\text { (weeks) }\end{array}$} & \multicolumn{4}{|c|}{ Mean testis weight $(m g) \pm S . E$. } & \multicolumn{3}{|c|}{$\mathrm{t}$ for comparisonst of } \\
\hline & \multicolumn{2}{|c|}{ Right testis } & \multicolumn{2}{|c|}{ Left testis } & (1) and (2) & (3) and (4) & (1) and (3) \\
\hline & (1) Intact & $\begin{array}{l}\text { (2) Hemi- } \\
\text { castrated }\end{array}$ & (3) Intact & $\begin{array}{l}\text { (4) Hemi- } \\
\text { castrated }\end{array}$ & & & \\
\hline $4 \frac{1}{2}$ & $\begin{array}{r}58 \cdot 2 \\
\pm 5 \cdot 6 \\
(5)^{*}\end{array}$ & & $\begin{array}{c}62 \cdot 4 \\
\pm 4 \cdot 7 \\
(5)\end{array}$ & & & & 0.57 \\
\hline $5 \frac{1}{2}$ & $\begin{array}{c}82 \cdot 4 \\
\pm 8 \cdot 2 \\
(5)\end{array}$ & $\begin{array}{r}83 \cdot 2 \\
\pm 2 \cdot 6 \\
(5)\end{array}$ & $\begin{array}{c}67 \cdot 2 \\
\pm 7 \cdot 1 \\
(5)\end{array}$ & $\begin{array}{r}85 \cdot 2 \\
\pm 10 \cdot 9 \\
(5)\end{array}$ & 0.09 & 1.03 & $1 \cdot 40$ \\
\hline $6 \frac{1}{2}$ & $\begin{array}{r}115 \cdot 6 \\
\pm 10 \cdot 3 \\
(5)\end{array}$ & $\begin{array}{r}100 \cdot 0 \\
\pm 11 \cdot 7 \\
(5)\end{array}$ & $\begin{array}{r}100 \cdot 6 \\
\pm 11.8 \\
(5)\end{array}$ & $\begin{array}{c}85 \cdot 8 \\
\pm 5 \cdot 8 \\
(5)\end{array}$ & 1.00 & $1 \cdot 13$ & 0.96 \\
\hline $7 \frac{1}{2}$ & $\begin{array}{c}124.2 \\
\pm 4 \cdot 8 \\
(5)\end{array}$ & $\begin{array}{c}122 \cdot 6 \\
\pm 11 \cdot 1 \\
(5)\end{array}$ & $\begin{array}{c}118 \cdot 4 \\
\pm 8 \cdot 2 \\
(5)\end{array}$ & $\begin{array}{c}115.6 \\
\pm 8.3 \\
(5)\end{array}$ & $0 \cdot 13$ & 0.24 & 0.61 \\
\hline
\end{tabular}

* No. of animals per group in parentheses.

$\dagger$ No comparisons were significant.

TABLE 2

COMPARISON OF TESTIS WEIGHTS FROM MIGE HEMICASTRATED 2 OR 3 WEEKS PREVIOUSLY AND INTAGT MIGE AT THE SAME AGE

\begin{tabular}{|c|c|c|c|c|c|c|c|}
\hline \multirow{3}{*}{$\begin{array}{c}\text { Age at } \\
\text { comparison } \\
\text { (weeks) }\end{array}$} & \multicolumn{4}{|c|}{ Mean testis weight $(m g) \pm S . E$. } & \multicolumn{3}{|c|}{$\mathrm{t}$ for comparisons $\dagger$ of } \\
\hline & \multicolumn{2}{|c|}{ Right testis } & \multicolumn{2}{|c|}{ Left testis } & \multirow{2}{*}{ (1) and (2) } & \multirow{2}{*}{ (3) and (4) } & \multirow{2}{*}{ (1) and (3) } \\
\hline & (1) Intact & $\begin{array}{l}\text { (2) Hemi- } \\
\text { castrated }\end{array}$ & (3) Intact & $\begin{array}{l}\text { (4) Hemi- } \\
\text { castrated }\end{array}$ & & & \\
\hline 3 & $\begin{array}{r}37.5 \\
\pm 3.8 \\
(11)^{*}\end{array}$ & & $\begin{array}{l}41.5 \\
\pm 1.6 \\
(12)\end{array}$ & & & & 0.98 \\
\hline 5 & $\begin{array}{c}102 \cdot 0 \\
\pm 2 \cdot 2 \\
(8)\end{array}$ & $\begin{array}{l}99 \cdot 6 \\
\pm 4 \cdot 0 \\
(12)\end{array}$ & $\begin{array}{c}97 \cdot 8 \\
\pm 10 \cdot 5 \\
(6)\end{array}$ & $\begin{array}{r}94 \cdot 7 \\
\pm 8 \cdot 8 \\
(11)\end{array}$ & 0.46 & $0 \cdot 22$ & 0.45 \\
\hline 6 & $\begin{array}{l}111 \cdot 9 \\
\pm 6 \cdot 1 \\
(12)\end{array}$ & & $\begin{array}{l}110 \cdot 8 \\
\pm 6 \cdot 5 \\
(11)\end{array}$ & & & & $0 \cdot 12$ \\
\hline 7 & $\begin{array}{c}139.5 \\
\pm 8 \cdot 3 \\
(4)\end{array}$ & $\begin{array}{c}114.5 \\
\pm 8 \cdot 0 \\
(4)\end{array}$ & $\begin{array}{c}118.5 \\
\pm 9.1 \\
(4)\end{array}$ & $\begin{array}{c}115 \cdot 7 \\
\pm 6 \cdot 2 \\
(3)\end{array}$ & $2 \cdot 16$ & $0 \cdot 24$ & $1 \cdot 70$ \\
\hline 13 & $\begin{array}{c}189.8 \\
\pm 19.4 \\
(6)\end{array}$ & & $\begin{array}{c}162 \cdot 7 \\
+10 \cdot 1 \\
(6)\end{array}$ & & & & $1 \cdot 24$ \\
\hline 15 & $\begin{array}{c}176.5 \\
\pm 11.9 \\
(6)\end{array}$ & $\begin{array}{r}181 \cdot 0 \\
\pm 12 \cdot 2 \\
(6)\end{array}$ & $\begin{array}{c}143 \cdot 3 \\
\pm 15 \cdot 1 \\
(6)\end{array}$ & $\begin{array}{c}190 \cdot 7 \\
\pm 19 \cdot 4 \\
(6)\end{array}$ & $0 \cdot 26$ & 1.93 & $1 \cdot 72$ \\
\hline 18 & $\begin{array}{c}171 \cdot 8 \\
\pm 13 \cdot 6 \\
(6)\end{array}$ & $\begin{array}{c}165 \cdot 2 \ddagger \\
\pm 17 \cdot 1 \\
(6)\end{array}$ & $\begin{array}{r}177 \cdot 4 \\
\pm 12 \cdot 7 \\
(5)\end{array}$ & $\begin{array}{c}185 \cdot 3 \ddagger \\
\pm 13 \cdot 0 \\
(6)\end{array}$ & $0 \cdot 31$ & 0.43 & 0.29 \\
\hline
\end{tabular}

* No. of animals per group in parentheses.

$\uparrow$ No comparisons were significant.

¥ Mice killed 3 weeks after hemicastration: elsewhere mice killed 2 weeks after hemicastration. 

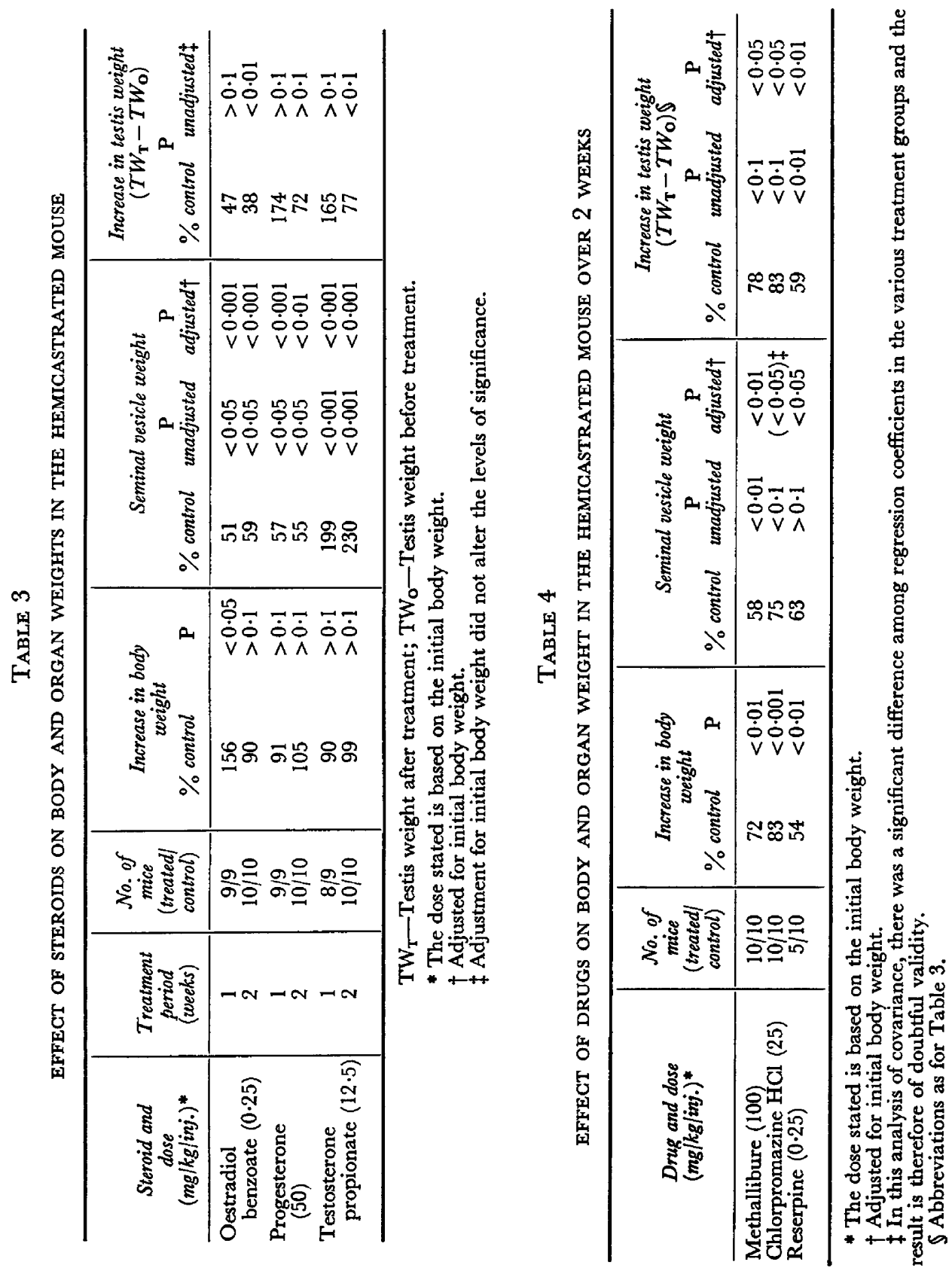
Table 4 shows the results of treatment with three non-steroid drugs which were expected to have antigonadotrophic activity: all reduced seminal vesicle and testis weight. The levels of significance of the effects are shown in the table, but it should be noted that they also caused reduction in body growth.

Low doses of reserpine $(0.05 \mathrm{mg} / \mathrm{kg} /$ injection $)$ produced unexpected results. When the drug was given for 1 week, seminal vesicle weight was significantly increased (to $161 \%$ of the control values: $P<0.01$ ): when the drug was given for 2 weeks the increase (to $127 \%$ of the control values) was not significant. A larger dose, $0.25 \mathrm{mg} / \mathrm{kg} /$ injection, reduced seminal vesicle weight (Table 4). In intact mice of the same age (unpublished observations), and in adult male rats (Brown \& Fawke, 1972), doses of reserpine in the region of $0.05 \mathrm{mg} / \mathrm{kg} /$ day have been found to increase seminal vesicle weight.

TABLE 5

EFFEGT OF $\alpha$-METHYL- $p$-TYROSINE AND $p$-GHLOROPHENYLALANINE ON BODY AND ORGAN WEIGHT IN THE HEMICASTRATED MOUSE OVER 2 WEEKS

\begin{tabular}{|c|c|c|c|c|c|}
\hline \multirow[b]{2}{*}{ Drug } & \multirow[b]{2}{*}{$\begin{array}{c}\text { Dose } \\
(\mathrm{mg} / \mathrm{kg} / \text { injection }) \dagger\end{array}$} & \multirow[b]{2}{*}{$\begin{array}{c}\text { No. of mice } \\
\text { (treated/control) }\end{array}$} & \multicolumn{3}{|c|}{$\begin{array}{c}\text { Results for treated mice as percentage of } \\
\text { results in controls }\end{array}$} \\
\hline & & & $\begin{array}{l}\text { Increase in } \\
\text { body weight } \$\end{array}$ & $\begin{array}{l}\text { Seminal } \\
\text { vesicle } \\
\text { weight }\end{array}$ & $\begin{array}{c}\text { Increase in } \\
\text { testis weight } \\
\left(T W_{\mathbf{T}}-T W_{\mathrm{O}}\right)\end{array}$ \\
\hline $\begin{array}{l}\alpha \text {-Methyl- } p \text {-tyrosine } \\
\alpha \text {-Methyl- } p \text {-tyrosine } \neq \\
\alpha \text {-Methyl- } p \text {-tyrosine } \$ \\
\alpha \text {-Methyl- } p \text {-tyrosine } \$\end{array}$ & $\begin{array}{r}100 \\
300 \\
150 \\
75\end{array}$ & $\begin{array}{l}5 / 9 \\
7 / 12 \\
6 / 12 \\
5 / 12\end{array}$ & $\begin{array}{r}113 \\
103 \\
101 \\
87\end{array}$ & $\begin{array}{l}100 \\
117 \\
103 \\
123\end{array}$ & $\begin{array}{r}99 \\
100 \\
108 \\
98\end{array}$ \\
\hline $\begin{array}{l}p \text {-Chlorophenylalanine } \\
p \text {-Chlorophenylalanine } \neq \\
p \text {-Chlorophenylalanine } \neq \\
p \text {-Ghlorophenylalanine } \neq \\
p \text {-Chlorophenylalanine } \ddagger\end{array}$ & $\begin{array}{r}100 \\
200 \\
300 \\
150 \\
75\end{array}$ & $\begin{array}{l}10 / 9 \\
10 / 9 \\
10 / 9 \\
10 / 9 \\
10 / 9\end{array}$ & $\begin{array}{r}96 \\
95 \\
93 \\
102 \\
99\end{array}$ & $\begin{array}{l}72^{*} \\
89 \\
80 \\
79^{*} \\
83\end{array}$ & $\begin{array}{r}100 \\
93 \\
91 \\
94 \\
97\end{array}$ \\
\hline
\end{tabular}

* Significant reduction $(P<0.05)$ after correction for initial body or testis weight. None of the other changes indicated were significant.

$t$ The dose stated is based on the initial body weight.

$¥$ Given as the methyl ester hydrochloride.

$\$$ Increase in body weight between the time of hemicastration and autopsy.

\section{Effects of drugs which inhibit the synthesis of catecholamines and 5-HT}

Treatment with MPT and GPA over 1 week produced no detectable effects on body weight or that of the seminal vesicles or testes: the results of treatment over 2 weeks are shown in Table 5. Treatment with MPT tended to raise seminal vesicle weight but not significantly. Treatment with CPA, on the other hand, consistently reduced seminal vesicle weight, and in two experiments the reduction was significant after covariant correction. Testis weight was not affected.

\section{DISCUSSION}

In the female mammal, compensatory hypertrophy after unilateral gonadectomy is a well-established phenomenon, but the results in males are conflicting: some workers found that compensatory hypertrophy occurs (Lip- 
schütz, 1922, 1923; Grant, 1957) while others disagree (Smelser, 1933). Our results in the mouse show no indication of compensatory hypertrophy in immature or mature animals over the short interval (1 to 3 weeks) studied. The reduction in seminal vesicle weight in hemicastrated mice compared with intact controls suggests that androgen output had been decreased. Sham operation was not performed so there is no measure of the effect of the surgical procedure on either testis or seminal vesicle growth. The reported difference in weight between right and left testis is similar to the finding of Bindon \& Waites (1968) in the same species.

When testing the effect of drugs, we had hoped to be able to distinguish between effects dependent on FSH and those on LH, the seminal vesicle being mainly under the influence of LH and the testes influenced more by FSH. In some groups of mice, differential effects were obtained. For example, both oestradiol and progesterone reduced seminal vesicle weight yet only oestradiol reduced testis weight significantly. With these steroids, however, a direct effect on the sex organs may complicate interpretation in terms of gonadotrophin secretion.

With chlorpromazine, reserpine and methallibure, seminal vesicle weight and gain in testis weight were reduced but gain in body weight was also significantly reduced (Table 4). This made the effects on organ weight difficult to evaluate. However, it was thought that the reduction in testis weight caused by these drugs was not merely a reflection of somatic weight change because in experiments not described in this paper, a variety of drugs have been found to cause marked depression of body weight without reducing testis weight. The reduction in seminal vesicle and testis weight caused by the higher doses of reserpine was expected from the results of Gaunt, Renzi, Antonchak, Miller \& Gilman (1955) but the effect of low doses of reserpine in increasing seminal vesicle weight cannot at present be explained. The drug could be acting anywhere in the hypothalamic-pituitary-gonadal system, or directly on the seminal vesicle.

The test situation was used to study the effects of MPT, which inhibits the synthesis of catecholamines (Spector, Sjoerdsma \& Udenfriend, 1965), and of CPA, which inhibits the synthesis of 5-HT (Koe \& Weissman, 1966). The only significant finding was a consistent reduction in seminal vesicle weight caused by CPA. This could result from a reduction in the secretion of $L H$ or from interference with its effects. In the former case, it would suggest that 5-HT plays an excitatory rôle in the hypothalamic mechanisms leading up to LH release in the male mouse. This is completely at variance with the rôle suggested for 5-HT in controlling the ovulatory surge of LH secretion in the female rat (Kordon, Javoy, Vassent \& Glowinski, 1968), but is consistent with the findings suggesting that CPA inhibits the release of ovulating hormone in immature mice (Brown, 1968). Treatment with CPA also appears to inhibit the secretion of FSH in maturing female rats (Brown, 1971) and in adult male rats (Brown \& Fawke, 1972).

The use of hemicastrated mice theoretically offers advantages over the use of intact mice in studying antigonadotrophic drugs. In hemicastrated animals, it is possible to study the effect of such drugs on testicular growth during the 
experimental period whereas in intact mice, the final testis weight can only be corrected for body weight before treatment $\left(\mathrm{BW}_{\mathbf{0}}\right)$. In fifty-six out of sixty groups of hemicastrated mice receiving drugs, there was a higher degree of correlation of testis weight after treatment $\left(\mathrm{TW}_{\mathbf{T}}\right)$ with testis weight before treatment $\left(\mathrm{TW}_{\mathrm{o}}\right)$ than with $\mathrm{BW}_{\mathrm{o}}$. This suggests that hemicastration may be useful, but direct experimental comparisons between hemicastrated and intact mice after drug treatment were not made. Partial adjustment for $\mathrm{TW}_{\mathrm{o}}$ can be achieved by using $\left(\mathrm{TW}_{\mathrm{T}}-\mathrm{TW}_{\mathrm{o}}\right)$. This parameter can then be further corrected for $\mathrm{BW}_{\mathrm{o}}$, a procedure shown to be useful (see Tables 3 and 4) and having the advantage of taking into account another important variable. The findings with seminal vesicle weight are different. In over half the experimental groups, organ weight was more highly correlated with $\mathrm{BW}_{\mathrm{O}}$ than with $\mathrm{TW}_{\mathrm{o}}$ and correction for $\mathrm{BW}_{\mathrm{o}}$ is better than for $\mathrm{TW}_{\mathrm{o}}$. The advantage gained by the correction of seminal vesicle weight for $\mathrm{BW}_{\mathrm{o}}$ can be judged from the values of $P$ quoted in Tables 3 and 4 . The validity of such corrections is supported by the findings that (1) variance, examined by Bartlett's test, was homogeneous amongst treatment groups in most instances, and (2) the difference in regression coefficients for organ weight on body weight between treatment groups was significant in only one of the experiments described here (see footnote to Table 4).

\section{ACKNOWLEDGMENTS}

This work was supported in part by grants from the Population Council and the Smith Kline and French Foundation. We are grateful to Dr A. L. Walpole and ICI Ltd for supplies of methallibure.

\section{REFERENCES}

Bindon, B. M. \& Wartes, G. M. H. (1968) Discrepancy in weight and blood flow of the left and right testis and epididymis of the mouse before and after hypophysectomy. F. Endocr. 40, 385.

Brown, P. S. (1968) The effect of drugs on induced ovulation. F. Reprod. Fert. Suppl. 4, 61.

BRown, P. S. (1971) Pituitary follicle-stimulating hormone in immature female rats treated with drugs which inhibit the synthesis or antagonise the actions of catecholamines and 5-hydroxytryptamine. Neuroendocrinology, 7, 183.

BRown, P. S. \& FAwKe, L. (1972) Effects of reserpine, p-chlorophenylalanine, $\alpha$-methyltyrosine, thymoxamine or methallibure on pituitary FSH in male rats. F. Reprod. Fert. 28, 167.

Burack, W. R., Weiner, N. \& Hagen, P. B. (1960) The effect of reserpine on the catecholamine and adenine nucleotide content of adrenal glands. F. Pharmac. exp. Ther. 130, 245.

Gaunt, R., Renzi, A. A., Antonchak, N., Miller, G. J. \& Gilman, M. (1955) Endocrine aspects of the pharmacology of reserpine. Ann. N.Y. Acad. Sci. 59, 22.

Grant, J. H. (1957) The effects of unilateral orchidectomy on the rat testis. Proc. Soc. Study Fert. 8, 27.

Koe, B. K. \& Weissman, A. (1966) p-Chlorophenylalanine: a depletor of brain serotonin. 7. Pharmac. exp. Ther. 154, 499.

Kordon, C., Javoy, F., Vassent, G. \& Glowinski, J. (1968) Blockade of superovulation in the immature rat by increased brain serotonin. Europ. F. Pharmac. 4, 169.

LipschüTz, A. (1922) The so-called compensatory hypertrophy of the testicle after unilateral castration. F. Physiol., Lond. 56, 451.

Lipschürtz, A. (1923) Castration unilatérale chez la souris blanche. C.r. Séanc. Soc. Biol. 89, 1137.

Smelser, G. K. (1933) Compensatory hyper-activity of the testis following unilateral castration. Anat. Rec. 57, Suppl. 1, 28.

SNedecor, G. W. (1937) Statistical methods, p. 318. Iowa State College Press, Iowa.

Spector, S., Sjofrdsma, A. \& Udenfriend, S. (1965) Blockade of endogenous norepinephrine synthesis by $\alpha$-methyltyrosine, an inhibitor of tyrosine hydroxylase. F. Pharmac. exp. Ther. 147, 86. 